\title{
Human chorionic gonadotropin and its relation to grade, stage and patient survival in ovarian cancer
}

\author{
Miriam Lenhard ${ }^{1 *}$, Alexandra Tsvilina ${ }^{2}$, Lan Schumacher ${ }^{2}$, Markus Kupka², Nina Ditsch, Doris Mayr ${ }^{3}$, Klaus Friese $^{1,2}$ \\ and Udo Jeschke ${ }^{2}$
}

\begin{abstract}
Background: An influence of gonadotropins (hCG) on the development of ovarian cancer has been discussed. Therefore, we quantified serum hCG levels in patients with benign and malignant ovarian tumors and the hCG expression in ovarian cancer tissue in order to analyze its relation to grade, stage, gonadotropin receptor (LH-R, FSH-R) expression and survival in ovarian cancer patients.

Methods: Patients diagnosed and treated for ovarian tumors from 1990 to 2002 were included. Patient characteristics, histology including histological subtype, tumor stage, grading and follow-up data were available. Serum hCG concentration measurement was performed with ELISA technology, hCG tissue expression determined by immunohistochemistry.

Results: HCG-positive sera were found in $26.7 \%$ of patients with benign and $67 \%$ of patients with malignant ovarian tumors. In addition, significantly higher hCG serum concentrations were observed in patients with malignant compared to benign ovarian tumors $(p=0.000$ ). Ovarian cancer tissue was positive for $\mathrm{hCG}$ expression in $68 \%$. We identified significant differences in hCG tissue expression related to tumor grade $(p=0.022)$ but no differences with regard to the histological subtype. In addition, mucinous ovarian carcinomas showed a significantly increased hCG expression at FIGO stage III compared to stage I ( $p=0.018$ ). We also found a positive correlation of hCG expression to LH-R expression, but not to FSH-R expression. There was no significant correlation between tissue hCG expression and overall ovarian cancer patient survival, but subgroup analysis revealed an increased 5-year survival in LH-R positive/FSH-R negative and hCG positive tumors (hCG positive $75.0 \%$ vs. hCG negative 50.5\%).
\end{abstract}

Conclusions: Serum human gonadotropin levels differ in patients with benign and malignant ovarian tumors. HCG is often expressed in ovarian cancer tissue with a certain variable relation to grade and stage. HCG expression correlates with LH-R expression in ovarian cancer tissue, which has previously been shown to be of prognostic value. Both, the hormone and its receptor, may therefore serve as targets for new cancer therapies.

Keywords: hCG, LH receptor, Ovarian cancer, Prognosis

\section{Background}

Due to missing early clinical symptoms, ovarian cancer is often diagnosed at an advanced stage [1]. Primary treatment includes operative cytoreduction and subsequent combined platinum-based chemotherapy. Though

\footnotetext{
* Correspondence: Miriam.lenhard@med.uni-muenchen.de ${ }^{1}$ Department of Obstetrics and Gynecology, Grosshadern Campus, LudwigMaximilians-University Hospital, Marchioninistrasse 15, 81377 Munich, Germany

Full list of author information is available at the end of the article
}

reported primary response rates range around $80 \%$, ovarian cancer is the most lethal gynecological malignancy since $60-70 \%$ of patients relapse or die within 5 years after primary diagnosis [2-4].

The molecular mechanism of ovarian cancer development is still discussed controversially [5]. As ovaries are the target organs of gonadotropins, a relation to the development or growth of ovarian cancer has been postulated [6]. An increased risk for the development of ovarian cancer was assumed in women treated for 
infertility who had therefore been stimulated with gonadotropins [7-9].

Human gonadotropin (hCG) is expressed in placental trophoblasts, but also in a large number of tumors. HCG and the gonadotropin luteal hormone (LH) bind to the same receptor (LH-R) and have similar biological functions, although hCG is more potent because of its higher receptor binding affinity and its longer circulatory half life. Human chorionic gonadotropin is a glycoprotein produced by the fetal trophoblast during pregnancy and is secreted into the maternal circulation [10]. The commitment of cytotrophoblasts to syncytiotrophoblasts is associated with activation of $\alpha$ - and $\beta$ hCG subunit genes [11]. These intermediates are transient, they differentiate to syncytiotrophoblasts and the expression of $\beta$-hCG RNA declines [12]. Also in chorion carcinoma cells consisting of clusters of cytotrophoblastlike and large multinucleated cells, $\alpha$ - and $\beta$-hCG RNA is expressed [13]. In these cells, hCG has been used as a tumor marker for a long time [14].

There are only few studies with small patient numbers on human chorionic gonadotropin and its receptor expression in ovarian cancer tissue $[15,16]$. In a previous study we found a prognostic value of LH-R and FSH-R in ovarian cancer patients [17]. The present study was designed to further analyze hCG expression in a large cohort of ovarian cancer patients and its relation to histological subtype, grade, stage, gonadotropin receptor expression and patient survival. In addition, we determined hCG serum concentrations in patients with ovarian cancer and compared the results to patients with benign ovarian tumors.

\section{Methods}

\section{Sera}

Sera of patients diagnosed with an ovarian tumor between 2003 and 2006 were obtained before surgery and stored at $-80^{\circ} \mathrm{C}$. After surgery, histological diagnostic evaluation including staging and grading of tumor tissue were performed by an experienced gynecologic pathologist (D.M.) according to the criteria of the International Federation of Gynaecologists and Obstetricians (FIGO) and the World Health Organization (WHO).

\section{Tissue samples}

All tissue samples were gained at surgery in patients who had been treated for primary ovarian cancer at our institution between 1990 and 2002. Staging and grading were performed by an experienced gynecologic pathologist according to the criteria of the International Federation of Gynaecologists and Obstetricians (FIGO) and the World Health Organization (WHO). Patients with ovarian borderline tumor were excluded from the study. Clinical data of the patients' disease were available from patient charts, aftercare files and tumor registry database information. The main outcomes assessed were disease recurrence and patient survival.

\section{Ethics approval}

The study has been approved by the local ethics committee of the Ludwig-Maximilians University Munich (approval with the reference number 138/03) and has been carried out in compliance with the guidelines of the Helsinki Declaration of 1975. The study participants gave their written informed consent and samples and clinical information were used anonymously.

\section{hCG-ELISA}

Concentration of hCG was obtained by an ELISA and using the Immulite 2000 automated diagnostic system (Siemens, Munich, Germany). Standard deviation for precision at $6.5 \mathrm{~m} \mathrm{IU} / \mathrm{ml}$ is 0.43 with a variation coefficient $(\mathrm{CV})$ of $6.6 \%$. Precision analysis showed no cross reactivity with human FSH (26.8 $\mathrm{ng} / \mathrm{ml}$ analyzed), LH (16.5 $\mathrm{ng} / \mathrm{ml}$ analyzed) or TSH (860 $\mathrm{ng} / \mathrm{ml}$ analyzed).

Immunohistochemistry was performed as previously described elsewhere, using a combination of pressure cooker heating and the standard streptavidin-biotin-peroxidase complex with the use of the rabbit-IgG-Vectastain Elite ABC kit (Vector Laboratories, Burlingame, CA) $[18,19]$. Antibodies used for staining were the antihCG $(17.75 \mu \mathrm{g} / \mathrm{ml}$, rabbit IgG, polyclonal, dilution 1:400, Dako, Glostrup, Denmark) and anti-LH (LH/hCG-R, 1 $\mathrm{mg} / \mathrm{ml}$, rabbit IgG, polyclonal, dilution 1:25, Dianova, Hamburg, Germany).

In short, paraffin-fixed tissue sections were dewaxed with xylol for $15 \mathrm{~min}$ and then dehydrated in ascending concentrations of alcohol (70\%, 96\%, and 100\%). Afterwards, they were exposed for epitope retrieval for 10 min in a pressure cooker using sodium citrate buffer ( $\mathrm{pH}$ 6.0) containing $0.1 \mathrm{M}$ citric acid and $0.1 \mathrm{M}$ sodium citrate in distilled water. After cooling, slides were washed in PBS twice. Endogenous peroxidase activity was quenched by dipping in 3\% hydrogen peroxide (Merck, Darmstadt, Germany) in methanol for $20 \mathrm{~min}$. Non-specific binding of the primary antibodies was blocked by incubating the sections with "diluted normal serum" (10 ml PBS containing $150 \mu \mathrm{l}$ horse serum; Vector Laboratories, CA) for $20 \mathrm{~min}$ at room temperature. Then, slides were incubated with the primary antibodies at room temperature for $60 \mathrm{~min}$. After washing with PBS, slides were incubated in "diluted biotinylated serum" (10 ml PBS containing $50 \mu \mathrm{l}$ horse serum; Vector Laboratories, CA) for $30 \mathrm{~min}$ at room temperature. After incubation with the avidin-biotin-peroxidase complex (diluted in $10 \mathrm{ml}$ PBS, Vector Laboratories, CA) for 30 min and repeated PBS washing, visualization was conducted using substrate and chromagen 3,3'- 
diaminobenzidine (DAB; Dako, Glostrup, Denmark) for 8-10 min. Slides were then counterstained with Mayer's acidic hematoxylin and dehydrated in ascending concentrations of alcohol (50-98\%). After xylol treatment, slides were covered.

Placental tissue at 3rd trimenon served as a positive control for the hCG and LH-R staining, accordingly. For negative controls, primary antibody was replaced with normal control serum rabbit IgG (BioGenex, San Ramon, USA). Positive staining resulted in brownish color, negative controls as well as unstained cells in blue color.

\section{Immunohistochemical analysis}

Slides were evaluated and digitalized with a Zeiss photomicroscope (Axiophot, Axiocam, Zeiss, Jena, Germany). Immunohistochemical staining was assessed using a semiquantitative score according to Remmele and Stegner [20], comprising optical staining intensity (graded as $0=$ no, $1=$ weak, $2=$ moderate, and $3=$ strong staining) and the percentage of positively stained cells $(0=$ no, $1=<10 \%, 2=11-50 \%, 3=51-80 \%$ and 4 $=>81 \%$ cells). According to previously published data, we scored the tumor tissue as positive if more than $10 \%$ of cells were scored with an immunoreactive score (IRS) higher than 2 [15]. The slides were reviewed in a blinded fashion by two independent observers, including a gynecological pathologist (D.M.).

\section{Statistical analysis}

Statistical analysis was performed using SPSS 18.0 (PASW Statistic, SPSS Inc., IBM, Chicago, IL). Correlation analysis of the receptor expression was performed for the histological subtype, tumor stage, grading and clinical data using the non-parametric Kruskal-Wallis rank-sum test and the non-parametric Spearman correlation coefficient. For the comparison of survival times, Kaplan-Meier curves were drawn. The chi-square statistic of the log-rank test was calculated to test differences between survival curves for significance. $\mathrm{P}$ values below 0.05 were considered statistically significant.

\section{Results}

\section{Patient characteristics}

Sera of 123 patients diagnosed with either benign ( $\mathrm{n}=$ $83)$ or malignant $(n=40)$ ovarian tumors were obtained before surgery to test for serum hCG levels. Among the patients with benign ovarian tumors were cystadenomas $(\mathrm{n}=12)$, simple ovarian cysts $(\mathrm{n}=25)$, endometriosis ( $\mathrm{n}$ $=9)$, teratomas $(n=10)$, fibromas $(n=8)$ and other tumors $(n=18)$. Patients with ovarian carcinomas mostly presented at stage III or IV (FIGO I: $15.4 \%$, FIGO II: $11.5 \%$, FIGO III: $53.8 \%$ and FIGO IV: $19.2 \%$ ). Patients with borderline tumors of the ovary are neither included in the benign nor in the ovarian cancer patient group.

Paraffin embedded tissue of 156 ovarian cancer patients was available. Median age at primary diagnosis was 58 years (range 18-88). Most patients presented with progressed disease at primary diagnosis [FIGO I: $\mathrm{n}$ $=35$ (22.6\%), FIGO II: $\mathrm{n}=9$ (5.8\%), FIGO III: $\mathrm{n}=109$ (70.3\%), FIGO IV: $\mathrm{n}=2(1.3 \%)]$. Patient characteristics are detailed in Table 1. Median follow-up time was 7.3 years (range 0.3-16.8) with 26 documented relapses and 91 deaths. Median relapse free survival was 2.1 years (range 0.9-7.2) and median overall survival 5.9 years (range 0.3-16.6) (Table 1).

\section{hCG ELISA}

In serum analysis, we found hCG-positive sera in $26.7 \%$ of patients with benign ovarian tumors and $67 \%$ positive sera in patients with malignant ovarian tumors. In addition, we identified significant differences in hCG concentration in benign compared to malignant diseases of the ovaries $(p=0.000)$. The median calculation has been done using all samples, i.e. negative samples were also included in the calculation. Median hCG concentration in patient sera with benign ovarian tumors was 0.1 $\mathrm{mU} / \mathrm{ml}$ and $4 \mathrm{mU} / \mathrm{ml}$ in patients with malign ovarian tumors (Figure 1).

\section{hCG expression in ovarian cancer tissue}

Immunohistochemical analysis revealed hCG positive tumors in $68 \%$ of all cancer tissues investigated (Figure $2 \mathrm{a}, \mathrm{b})$. Only slight differences in hCG expression could be observed with respect to the histological subtype, with lowest expression in clear cell carcinomas and highest in mucinous ovarian carcinomas (Figure 3a). Regarding tumor grade, we identified significant differences in hCG expression among G1, G2 and G3 carcinomas (Figure $3 \mathrm{~b}, \mathrm{p}=0.022$ ). With respect to tumor stage, a significant difference was observed in mucinous tumors at stage FIGO I compared FIGO II and FIGO III ( $p=0.018$, Figure 3c).

In addition, a positive correlation of hCG to LHreceptor expression (correlation coefficient 0.194, $p=$ 0.037 , Table 2) was identified. Interestingly, there was no correlation of hCG expression and FSH-receptor expression.

\section{Prognostic value of hCG}

Statistical analysis was performed to test for a prognostic value of hCG expression in ovarian cancer tissue. The univariate Kaplan Meier analysis reveals no statistical difference between patients positive and negative for hCG in ovarian cancer tissue $(p=0.618)$. Interestingly, there was an increased 5-year survival in patients with hCG positive tumors in the LH-R positive/FSH-R 
Table 1 Patient characteristics of ovarian cancer patients whose tissue samples were stained by immunohistochemistry for hCG expression or serum samples were analyzed for hCG concentration

\begin{tabular}{llll}
\hline & & Tissue samples & Serum samples \\
\hline Ovarian cancer patients ( $)$ & & 156 & 40 \\
\hline Age at primary diagnosis (a) & & 58 (range 18-88) & 62 (range 21-80) \\
\hline Histology (\%) & serous & 70.5 & 81.0 \\
\cline { 2 - 4 } & mucinous & 13.5 & 4.8 \\
\cline { 2 - 4 } & endometrioid & 7.7 & 14.3 \\
\cline { 2 - 4 } & clear cell & 8.3 & 0.0 \\
\hline Tumor grading (\%) & low grade & 27.2 & 4.2 \\
\cline { 2 - 4 } & intermediate & 36.5 & 54.2 \\
\cline { 2 - 4 } & high grade & 36.3 & 13.9 \\
\hline Tumor stage (FIGO) (\%) & I & 22.6 & 13.9 \\
\cline { 2 - 4 } & II & 5.8 & 55.6 \\
\cline { 2 - 4 } & IV & 70.3 & 16.7 \\
\hline Gonadotropin receptor expression (\%) & LH-R positive & 64.3 & - \\
\hline
\end{tabular}

negative subgroup (5-year survival: hCG positive $75.0 \%$ vs. hCG negative 50.5\%; Figure 4, Table 3).

\section{Discussion}

To date, the pathogenesis and progression of ovarian cancer remains unclear. There are various hypotheses to

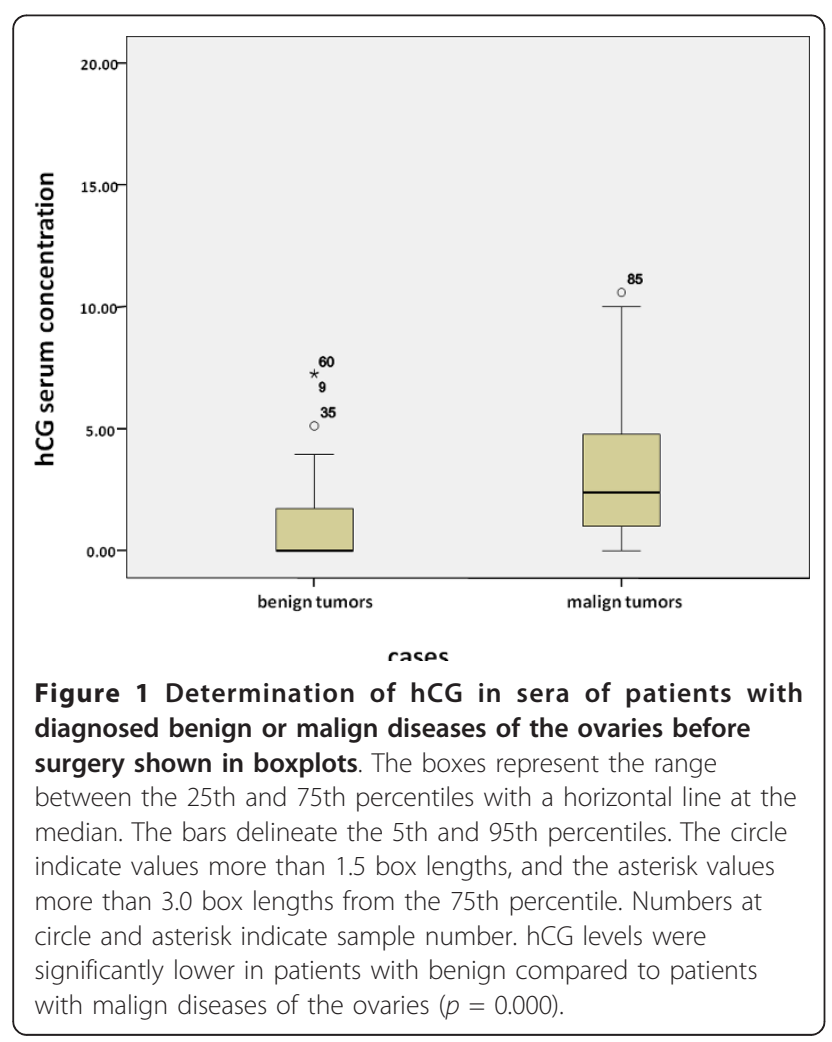

explain its etiology, two of them discussing hormonal influence on tumorgenesis [6,21-23]. Some risk factors for the development of ovarian cancer like nulliparity and infertility have been identified in epidemiologic studies [21,24-26]. Ovarian cancer is often diagnosed in postmenopausal women who present with high gonadotropin blood serum levels [27]. Until today, the influence of hormones, especially gonadotropins, on the development or progression of ovarian cancer remains under discussion $[23,27,28]$.

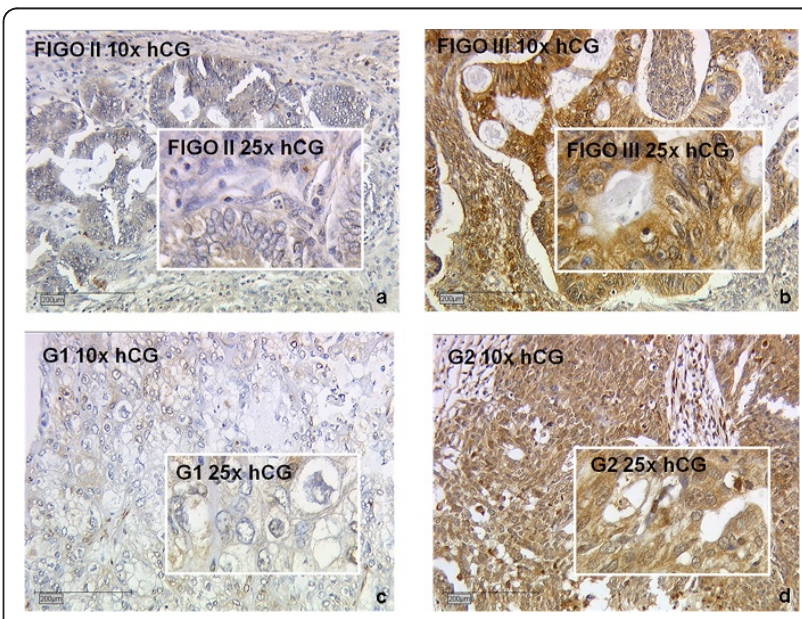

Figure 2 Representative slides of immunohistochemical staining for hCG expression for FIGO stage II (a, hCG negative), FIGO stage III (b, hCG positive) for grade 1 (c, weak hCG staining) and grade 2 (d, strong hCG staining) ovarian cancer tissue. No hCG immunoreactivity was detected in tumor stroma (magnification 10x and 25x). 

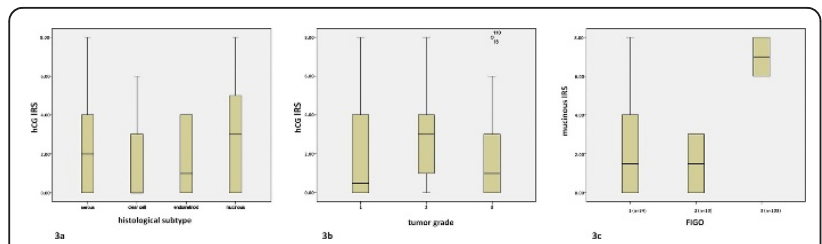

Figure 3 Expression of hCG in ovarian cancer shown in boxplots. a Expression of hCG in ovarian cancer subtypes shown in boxplots. The boxes represent the range between the 25th and 75th percentiles with a horizontal line at the median. The bars delineate the 5th and 95th percentiles. There were no significant differences in hCG expression between serous, clear cell, endometrioid or mucinous forms of ovarian cancer. $\mathbf{b}$ Expression of hCG in all ovarian cancer subtypes shown in boxplots regarding to grading. We identified significant differences in G1, G2 and G3 carcinomas $(p=0.022)$. The boxes represent the range between the 25th and 75th percentiles with a horizontal line at the median. The bars delineate the 5 th and 95 th percentiles. The circle indicates values more than 1.5 box lengths. c Expression of hCG in the mucinous ovarian cancer subtype shown in boxplots regarding to staging. We identified significant differences in FIGO I, FIGO II and FIGO III carcinomas $(p=0.018)$. The boxes represent the range between the 25th and 75th percentiles with a horizontal line at the median. The bars delineate the 5th and 95th percentiles.

In this study, serum human gonadotropin (hCG) levels differ between patients with benign and malignant ovarian tumors. HCG and its subunits can be measured at low dose in the serum of most men and women [29]. Its values differ according to the level of gonadotropin releasing hormone [30] and it is assumed that most of

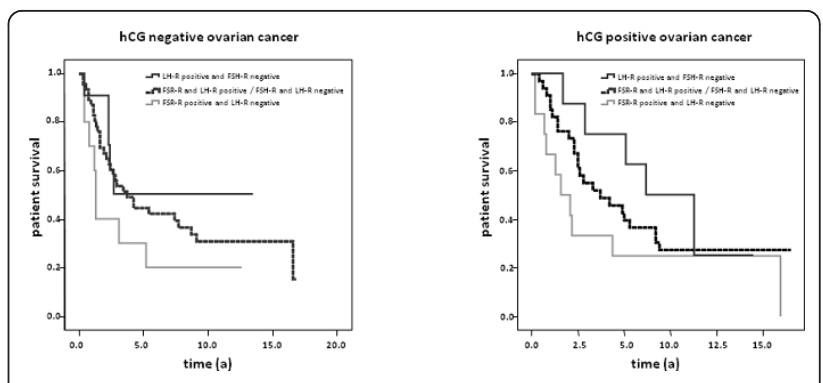

Figure 4 Kaplan-Meyer analysis indicating survival in subgroups of patients with or without hCG expression in ovarian cancer tissue samples.

hCG in serum of healthy persons originates from the pituitary. Studies on hCG-immonoreactivity have demonstrated that hCG is often elevated in serum of patients with gynecological cancers [31]. Still, hCG serum levels seem not to be useful in the diagnosis or therapy monitoring of non-trophoblastic gynecological malignancies $[32,33]$. But since there is evidence supporting that hCG is produced by gynecological cancers themselves [34-36], hCG production can be suspected to have an influence on gonadotropin receptor expression in cancer tissue. The fact that we observed a positive correlation of hCG to LH-receptor expression supports this assumption.

Among non-trophoblastic cancers, hCG expression is best analyzed in the transitional cell carcinoma of the bladder and urinary tract. The appearance of human

Table 2 Correlation between hCG, LH-receptor and FSH-receptor expression in all ovarian cancer subtypes

\begin{tabular}{|c|c|c|c|c|c|c|c|c|}
\hline \multicolumn{9}{|c|}{ Correlations } \\
\hline & & & hCG (Int) & hCG (IRS) & LH-R (Int) & LH-R (IRS) & FSH-R (Int) & FSH-R (IRS) \\
\hline \multirow[t]{15}{*}{ Spearman's rho } & hCG (Int) & Correlation Coefficient & 1.00 & $0.94^{* *}$ & 0.13 & $0.19^{*}$ & -0.09 & 0.01 \\
\hline & & Sig. (2-tailed) & & $<0.01$ & & 0.04 & & \\
\hline & $\overline{\mathrm{hCG}(\mathrm{IRS})}$ & Correlation Coefficient & $0.94^{* *}$ & 1.00 & 0.12 & $0.19 *$ & -0.01 & 0.09 \\
\hline & & Sig. (2-tailed) & $<0.01$ & & & 0.04 & & \\
\hline & & $\mathrm{N}(\mathrm{Int} / \mathrm{IRS})$ & 143 & 143 & 116 & 116 & 114 & 113 \\
\hline & LH-R (Int) & Correlation Coefficient & 0.13 & 0.12 & 1.00 & $0.90^{* *}$ & $0.23^{*}$ & $0.23^{*}$ \\
\hline & & Sig. (2-tailed) & & & & $<0.01$ & 0.01 & 0.01 \\
\hline & LH-R (IRS) & Correlation Coefficient & $0.19^{*}$ & $0.19 *$ & $0.90^{* *}$ & 1.00 & $0.21^{*}$ & $0.24^{*}$ \\
\hline & & Sig. (2-tailed) & 0.04 & 0.04 & $<0.01$ & & 0.03 & 0.01 \\
\hline & & $\mathrm{N}(\operatorname{lnt} / \mathrm{RS})$ & 116 & 116 & 120 & 120 & 116 & 115 \\
\hline & FSH-R (Int) & Correlation Coefficient & -0.09 & -0.01 & $0.23^{*}$ & $0.21^{*}$ & 1.00 & $0.87^{* *}$ \\
\hline & & Sig. (2-tailed) & & & 0.01 & 0.03 & & 0.01 \\
\hline & FSH-R (IRS) & Correlation Coefficient & 0.002 & 0.09 & $0.23^{*}$ & $0.24^{*}$ & $0.87^{* *}$ & 1.00 \\
\hline & & Sig. (2-tailed) & & & 0.01 & 0.01 & $<0.01$ & \\
\hline & & $N(\operatorname{lnt} / \mid \mathrm{RS})$ & 113 & 113 & 115 & 115 & 117 & 117 \\
\hline
\end{tabular}

We found a significant correlation between hCG and LH-receptor expression whereas hCG expression and FSH-receptor expression do not correlate with each other. (IRS = immunoreactive score, Int = staining intensity)

** Correlation is significant at the 0.01 level (2-tailed)

* Correlation is significant at the 0.05 level (2-tailed) 
Table 3 Ovarian cancer patient survival: 5-year survival for hCG positive and negative tumors with regard to LH receptor (LH-R) and FSH receptor (FSH-R) expression

\begin{tabular}{llcl}
\hline $\begin{array}{l}\text { Ovarian cancer patient 5-year } \\
\text { survival (\%) }\end{array}$ & $\begin{array}{l}\text { LH-R positive and FSH-R } \\
\text { negative }\end{array}$ & $\begin{array}{c}\text { FSR-R and LH-R positive/FSH-R and LH-R } \\
\text { negative }\end{array}$ & $\begin{array}{l}\text { FSH-R positive and LH-R } \\
\text { negative }\end{array}$ \\
\hline hCG negative & 50.5 & 44.9 & 30.0 \\
\hline hCG positive & 75.0 & 39.8 & 25.0 \\
\hline
\end{tabular}

chorionic gonadotropin within the tumor cells is described to be an evidence of dedifferentiation, since it is more commonly expressed in poorly differentiated tumors [37]. In this study, we also observed significant differences in hCG expression related to tumor grade ( $p$ $=0.022$ ) but no differences with regard to the histological subtype. In addition, mucinous ovarian carcinomas showed significantly increased hCG expression at FIGO stage $3(p=0.018)$. There is in vitro data with uterine microvascular endothelial cells showing hCG to increase capillary formation and migration of endothelial cells with no effect on cell proliferation [38]. In the same study by Zygmunt et al., hCG was found to induce neovascularization even in ovarian cancer in an in vivo animal model. Therefore, hCG was thought to be an important angiogenetic factor [38]. This finding may in part explain higher hCG expression in dedifferentiated tumors or higher stages in the mucinous ovarian cancer subgroup as observed in our own study. Still, there was no significant difference in patient survival relating to tumor hCG expression as it was found for transitional cell cancer of the bladder [39]. Therefore, we assume hCG to have varying functions in ovarian cancer, e.g. neovascularization or LH-R regulation, which might explain the partly contradictory findings of hCG effects in relation to histological results on the one hand and patient survival on the other.

Interestingly, we found a difference in 5-year survival rate between hCG-positive and hCG-negative tumors depending on LH-R or FSH-R expression. As demonstrated in our previous study, the LH-R and FSH-R themselves have prognostic value for patient's survival [17]. Our results showed a positive correlation of hCG tissue expression and LH-R expression. Therefore we assume hCG also to have an LH-R regulative function. The role of hCG and its receptors in cancer is discussed controversially in literature $[15,40]$. We have demonstrated here, that the contradictory findings in literature may also be explained by variable gonadotropin hormone and hormone receptor expression.

Gonadotropins bind to extracellular receptors, the LH-R and FSH-R. The LH-R receptor binds not only the gonadotropin LH but also hCG, and is therefore often referred to as LH/hCG-R. It is mainly found in gonadal tissue. Apart from gonadal tissue, it is known to be expressed in a variety of non-gonadal tissues in humans and rodents, like fetal tissues [41], the placenta [42], mammary gland [43], the salpinx, the uterus [44] or the cervix [45]. Most research on this receptor focuses on fertility-related treatments. Nonetheless, new therapeutic fields are evolving regarding this receptor since the LH/hCG-R is expressed in human cancer cells like breast cancer [46] or ovarian cancer [17]. To reduce the side-effects of chemotherapy, receptor-mediated therapies might be a new approach in anticancer treatment. Rahman et al. have developed a lytic peptide, hecate-CGbeta, which selectively kills cancer cells by changing their membrane potential [47]. Its effect on tumor cells has already been proven for breast cancer [46-48] and testicular tumors [49], but also for ovarian cancer $[49,50]$.

Gebauer et al. have analyzed the effect of human chorionic gonadotropin-doxorubicin on ovarian cancer cells and observed an increased activity of doxorubicin when conjugated to hCG [51]. This finding was also described for breast cancer cells [52]. The combination of cytostatic agents with hormones like hCG for the treatment of $\mathrm{LH} / \mathrm{hCG}-\mathrm{R}$ positive cells might be a promising approach to reduce morbidity and mortality in anticancer therapy. New therapeutic agents like lytic peptides or chemotherapeutic agents binding to the LH-R offer less toxic, but effective and selective anticancer treatment options, either alone or in combination with standard chemotherapeutic agents, in ovarian cancer patients whose tumors express these receptors.

Strengths of this study are the long follow-up time, the consistent pathologic histology review by expert gynecologic oncology pathologists and the large sample size. A limitation of this study is obviously the retrospective study design.

\section{Conclusions}

Serum human gonadotropin levels differ in patients with benign and malignant ovarian tumors. HCG is often expressed in ovarian cancer tissue with a certain variable relation to grade and stage. HCG expression correlates with LH-R expression in ovarian cancer tissue, which has previously been shown to be of prognostic value. Both, the hormone and its receptor, may therefore serve as targets for new cancer therapies, which may directly bind to hCG or its receptor LH-R and increase efficacy 
and specificity of anticancer treatment, thus reducing side effects.

\author{
Acknowledgements \\ We thank Susanne Kunze and Christina Kuhn for their assistance with \\ immunohistochemistry.
}

\section{Author details}

'Department of Obstetrics and Gynecology, Grosshadern Campus, LudwigMaximilians-University Hospital, Marchioninistrasse 15, 81377 Munich, Germany. ${ }^{2}$ Department of Obstetrics and Gynecology, Campus Innenstadt, Ludwig-Maximilians-University Hospital, Maistrasse 11, 80337 Munich, Germany. ${ }^{3}$ Department of Pathology, Ludwig-Maximilians-University Hospital, Thalkirchner Str. 36, 80337 Munich, Germany.

\section{Authors' contributions}

$\mathrm{ML}, \mathrm{AT}$ and LS have made substantial contributions to conception, design and acquisition of data. MK, ND and DM have made substantial contributions to analysis and interpretation of data, and have been involved in drafting the manuscript and revising it critically for important intellectual content. KF and UJ have given final approval of the version to be published. In addition, KF and UJ have made substantial contributions to conception and design of the study. All authors read and approved the final manuscript.

\section{Competing interests}

The authors declare that they have no competing interests.

Received: 14 September 2011 Accepted: 3 January 2012

Published: 3 January 2012

\section{References}

1. Cannistra SA: Cancer of the ovary. N Engl J Med 1993, 329(21):1550-1559.

2. Berek JS, Trope C, Vergote I: Surgery during chemotherapy and at relapse of ovarian cancer. Ann Oncol 1999, 10(Suppl 1):3-7.

3. Omura GA, Brady MF, Homesley HD, Yordan E, Major FJ, Buchsbaum HJ, Park RC: Long-term follow-up and prognostic factor analysis in advanced ovarian carcinoma: the Gynecologic Oncology Group experience. J Clin Oncol 1991, 9(7):1138-1150.

4. Thigpen JT, Vance RB, Khansur T: Second-line chemotherapy for recurrent carcinoma of the ovary. Cancer 1993, 71(4 Suppl):1559-1564.

5. Riman T, Nilsson S, Persson IR: Review of epidemiological evidence for reproductive and hormonal factors in relation to the risk of epithelial ovarian malignancies. Acta Obstet Gynecol Scand 2004, 83(9):783-795.

6. Risch HA: Hormonal etiology of epithelial ovarian cancer, with a hypothesis concerning the role of androgens and progesterone. J Natl Cancer Inst 1998, 90(23):1774-1786.

7. Rossing MA, Daling JR, Weiss NS, Moore DE, Self SG: Ovarian tumors in a cohort of infertile women. N Engl J Med 1994, 331(12):771-776.

8. Ness RB, Cramer DW, Goodman MT, Kjaer SK, Mallin K, Mosgaard BJ, Purdie DM, Risch HA, Vergona R, Wu AH: Infertility, fertility drugs, and ovarian cancer: a pooled analysis of case-control studies. Am J Epidemiol 2002, 155(3):217-224.

9. Whittemore AS, Harris R, Itnyre J: Characteristics relating to ovarian cancer risk: collaborative analysis of 12 US case-control studies. IV. The pathogenesis of epithelial ovarian cancer. Collaborative Ovarian Cancer Group. Am J Epidemiol 1992, 136(10):1212-1220.

10. Jeschke U, Toth B, Scholz C, Friese K, Makrigiannakis A: Glycoprotein and carbohydrate binding protein expression in the placenta in early pregnancy loss. J Reprod Immunol 2010, 85(1):99-105.

11. Hoshina M, Hussa R, Pattillo R, Camel HM, Boime I: The role of trophoblast differentiation in the control of the hCG and hPL genes. Adv Exp Med Biol 1984, 176:299-312.

12. Policastro PF, Daniels-McQueen S, Carle G, Boime I: A map of the hCG beta-LH beta gene cluster. J Biol Chem 1986, 261(13):5907-5916.

13. Jeschke U, Stahn R, Goletz C, Wang X, Briese V, Friese K: hCG in trophoblast tumour cells of the cell line Jeg3 and hCG isolated from amniotic fluid and serum of pregnant women carry oligosaccharides of the sialyl Lewis $\times$ and sialyl Lewis a type. Anticancer Res 2003, 23(2A):1087-1092.
14. Cole LA, Hartle RJ, Laferla JJ, Ruddon RW: Detection of the free beta subunit of human chorionic gonadotropin (HCG) in cultures of normal and malignant trophoblast cells, pregnancy sera, and sera of patients with choriocarcinoma. Endocrinology 1983, 113(3):1176-1178.

15. Zheng W, Lu JJ, Luo F, Zheng Y, Feng Y, Felix JC, Lauchlan SC, Pike MC: Ovarian epithelial tumor growth promotion by follicle-stimulating hormone and inhibition of the effect by luteinizing hormone. Gynecol Oncol 2000, 76(1):80-88.

16. Minegishi T, Kameda T, Hirakawa T, Abe K, Tano M, Ibuki Y: Expression of gonadotropin and activin receptor messenger ribonucleic acid in human ovarian epithelial neoplasms. Clin Cancer Res 2000, 6(7):2764-2770.

17. Lenhard M, Lennerova T, Ditsch N, Kahlert S, Friese K, Mayr D, Jeschke U: Opposed roles of follicle-stimulating hormone and luteinizing hormone receptors in ovarian cancer survival. Histopathology 2011, 58(6):990-994.

18. Jeschke U, Walzel H, Mylonas I, Papadopoulos P, Shabani N, Kuhn C, Schulze S, Friese K, Karsten U, Anz D, et al: The human endometrium expresses the glycoprotein mucin-1 and shows positive correlation for Thomsen-Friedenreich epitope expression and galectin-1 binding. $J$ Histochem Cytochem 2009, 57(9):871-881.

19. Mylonas I, Jeschke U, Shabani N, Kuhn C, Kunze S, Dian D, Friedl C, Kupka MS, Friese K: Steroid receptors ERalpha, ERbeta, PR-A and PR-B are differentially expressed in normal and atrophic human endometrium. Histol Histopathol 2007, 22(2):169-176.

20. Remmele W, Stegner HE: Recommendation for uniform definition of an immunoreactive score (IRS) for immunohistochemical estrogen receptor detection (ER-ICA) in breast cancer tissue. Pathologe 1987, 8(3):138-140.

21. Choi JH, Wong AS, Huang HF, Leung PC: Gonadotropins and ovarian cancer. Endocr Rev 2007, 28(4):440-461.

22. Cramer DW, Welch WR: Determinants of ovarian cancer risk. II. Inferences regarding pathogenesis. J Natl Cancer Inst 1983, 71(4):717-721.

23. Vanderhyden $B C$ : Loss of ovarian function and the risk of ovarian cancer. Cell Tissue Res 2005, 322(1):117-124.

24. Modugno F, Ness RB, Allen GO, Schildkraut JM, Davis FG, Goodman MT: Oral contraceptive use, reproductive history, and risk of epithelial ovarian cancer in women with and without endometriosis. Am J Obstet Gynecol 2004, 191(3):733-740.

25. Leung $\mathrm{PC}$, Choi $\mathrm{JH}$ : Endocrine signaling in ovarian surface epithelium and cancer. Hum Reprod Update 2007, 13(2):143-162.

26. Jernstrom $\mathrm{H}$, Borg $\mathrm{K}$, Olsson $\mathrm{H}$ : High follicular phase luteinizing hormone levels in young healthy BRCA1 mutation carriers: implications for breast and ovarian cancer risk. Mol Genet Metab 2005, 86(1-2):320-327.

27. Mandai M, Konishi I, Kuroda H, Fujii S: LH/hCG action and development of ovarian cancer-a short review on biological and clinical/epidemiological aspects. Mol Cell Endocrinol 2007, 269(1-2):61-64.

28. Chen FC, Oskay-Ozcelik G, Buhling KJ, Kopstein U, Mentze M, Lichtenegger $W$, Sehouli J: Prognostic value of serum and ascites levels of estradiol, FSH, LH and prolactin in ovarian cancer. Anticancer Res 2009, 29(5):1575-1578

29. Alfthan H, Haglund C, Dabek J, Stenman UH: Concentrations of human choriogonadotropin, its beta-subunit, and the core fragment of the beta-subunit in serum and urine of men and nonpregnant women. Clin Chem 1992, 38(10):1981-1987.

30. Stenman UH, Alfthan H, Ranta T, Vartiainen E, Jalkanen J, Seppala M: Serum levels of human chorionic gonadotropin in nonpregnant women and men are modulated by gonadotropin-releasing hormone and sex steroids. J Clin Endocrinol Metab 1987, 64(4):730-736.

31. Vaitukaitis JL: Human chorionic gonadotropin as a tumor marker. Ann Clin Lab Sci 1974, 4(4):276-280.

32. Rutanen EM, Seppala M: The hCG-beta subunit radioimmunoassay in nontrophoblastic gynecologic tumors. Cancer 1978, 41(2):692-696.

33. Samaan NA, Smith JP, Rutledge FN, Schultz PN: The significance of measurement of human placental lactogen, human chorionic gonadotropin, and carcinoembryonic antigen in patients with ovarian carcinoma. Am J Obstet Gynecol 1976, 126(2):186-189.

34. Carter PG, lles RK, Neven P, Ind TE, Shepherd JH, Chard T: The prognostic significance of urinary beta core fragment in premenopausal women with carcinoma of the cervix. Gynecol Oncol 1994, 55(2):271-276.

35. Grossmann M, Hoermann R, Gocze PM, Ott M, Berger P, Mann K: Measurement of human chorionic gonadotropin-related immunoreactivity in serum, ascites and tumour cysts of patients with gynaecologic malignancies. Eur J Clin Invest 1995, 25(11):867-873. 
36. Guo X, Liu G, Schauer IG, Yang G, Mercado-Uribe I, Yang F, Zhang S, He Y, Liu J: Overexpression of the beta subunit of human chorionic gonadotropin promotes the transformation of human ovarian epithelial cells and ovarian tumorigenesis. Am J Pathol 2011, 179(3):1385-1393.

37. Wurzel RS, Yamase HT, Nieh PT: Ectopic production of human chorionic gonadotropin by poorly differentiated transitional cell tumors of the urinary tract. J Urol 1987, 137(3):502-504.

38. Zygmunt M, Herr F, Keller-Schoenwetter S, Kunzi-Rapp K, Munstedt K, Rao CV, Lang U, Preissner KT: Characterization of human chorionic gonadotropin as a novel angiogenic factor. J Clin Endocrinol Metab 2002, 87(11):5290-5296.

39. Iles RK, Persad R, Trivedi M, Sharma KB, Dickinson A, Smith P, Chard T: Urinary concentration of human chorionic gonadotrophin and its fragments as a prognostic marker in bladder cancer. Br J Urol 1996, 77(1):61-69

40. Huang CF, Liu DY, Shen K: Follicle stimulating hormone inhibits cisplatin induced apoptosis in ovarian cancer cells. Zhongguo Yi Xue Ke Xue Yuan Xue Bao 2003, 25(4):447-450.

41. Abdallah MA, Lei ZM, Li X, Greenwold N, Nakajima ST, Jauniaux E: Rao Ch $\checkmark$ : Human fetal nongonadal tissues contain human chorionic gonadotropin/luteinizing hormone receptors. J Clin Endocrinol Metab 2004, 89(2):952-956.

42. Reshef E, Lei ZM, Rao CV, Pridham DD, Chegini N, Luborsky JL: The presence of gonadotropin receptors in nonpregnant human uterus, human placenta, fetal membranes, and decidua. J Clin Endocrinol Metab 1990, 70(2):421-430.

43. Tao YX, Lei ZM, Rao CV: The presence of luteinizing hormone/human chorionic gonadotropin receptors in lactating rat mammary glands. Life Sci 1997, 60(15):1297-1303.

44. Zhang M, Shi H, Segaloff DL, Van Voorhis BJ: Expression and localization of luteinizing hormone receptor in the female mouse reproductive tract. Biol Reprod 2001, 64(1):179-187.

45. Lin PC, Li X, Lei ZM: Rao Ch V: Human cervix contains functional luteinizing hormone/human chorionic gonadotropin receptors. J Clin Endocrinol Metab 2003, 88(7):3409-3414.

46. Leuschner C, Enright FM, Gawronska B, Hansel W: Membrane disrupting lytic peptide conjugates destroy hormone dependent and independent breast cancer cells in vitro and in vivo. Breast Cancer Res Treat 2003, 78(1):17-27

47. Rahman NA, Rao CV: Recent progress in luteinizing hormone/human chorionic gonadotrophin hormone research. Mol Hum Reprod 2009, 15(1):703-711.

48. Bodek G, Rahman NA, Zaleska M, Soliymani R, Lankinen H, Hansel W, Huhtaniemi I, Ziecik AJ: A novel approach of targeted ablation of mammary carcinoma cells through luteinizing hormone receptors using Hecate-CGbeta conjugate. Breast Cancer Res Treat 2003, 79(1):1-10.

49. Bodek G, Vierre S, Rivero-Muller A, Huhtaniemi I, Ziecik AJ, Rahman NA: A novel targeted therapy of Leydig and granulosa cell tumors through the luteinizing hormone receptor using a hecate-chorionic gonadotropin beta conjugate in transgenic mice. Neoplasia 2005, 7(5):497-508.

50. Gawronska B, Leuschner C, Enright FM, Hansel W: Effects of a lytic peptide conjugated to beta HCG on ovarian cancer: studies in vitro and in vivo. Gynecol Oncol 2002, 85(1):45-52.

51. Gebauer G, Mueller N, Fehm T, Berkholz A, Beck EP, Jaeger W, Licht P: Expression and regulation of luteinizing hormone/human chorionic gonadotropin receptors in ovarian cancer and its correlation to human chorionic gonadotropin-doxorubicin sensitivity. Am J Obstet Gynecol 2004, 190(6):1621-1628, discussion 1628.

52. Gebauer G, Fehm T, Beck EP, Berkholz A, Licht P, Jager W: Cytotoxic effect of conjugates of doxorubicin and human chorionic gonadotropin (hCG) in breast cancer cells. Breast Cancer Res Treat 2003, 77(2):125-131.

Pre-publication history

The pre-publication history for this paper can be accessed here: http://www.biomedcentral.com/1471-2407/12/2/prepub

doi:10.1186/1471-2407-12-2

Cite this article as: Lenhard et al: Human chorionic gonadotropin and its relation to grade, stage and patient survival in ovarian cancer. BMC Cancer 2012 12:2.

\section{Submit your next manuscript to BioMed Central and take full advantage of:}

- Convenient online submission

- Thorough peer review

- No space constraints or color figure charges

- Immediate publication on acceptance

- Inclusion in PubMed, CAS, Scopus and Google Scholar

- Research which is freely available for redistribution

Submit your manuscript at www.biomedcentral.com/submit 